Brazilian Journal of Forensic Sciences, Medical Law and Bioethics

Journal homepage: www.jpebj.com.br/forensicjournal

\title{
O Uso dos Marcadores Epigenéticos na Área Forense
}

\author{
The Use of Epigenetic Markers in the Forensic Area \\ Jéssica Sopran, Fernando Russo Costa do Bomfim* \\ Centro Universitário da Fundação Hermínio Ometto - FHO/UNIARARAS \\ * Corresponding author. Address: Av. Dr. Maximiliano Baruto, 500, Jardim Universitário, Araras - SP, \\ CEP 13607-339, E-mail: fernando_bomfim@live.com
}

Received 11 September 2018

Resumo. A criminalística sempre busca inovar as suas ideias de maneira a esclarecer a autoria e execução de um crime, de forma inegável. Por um longo período, a pesquisa de polimorfismos na sequência de DNA satélites ou DNA mitocondrial vem sendo aplicada na identificação criminal. Entretanto, esses métodos carregam limitações, apesar de serem frequentemente utilizados na identificação forense. Desta forma, este estudo visa a possibilidade da utilização de técnicas epigenéticas complementares as técnicas normalmente utilizadas na genética forense. O objetivo desta revisão de literatura é descrever o uso de marcadores epigenéticos, em particular a metilação do DNA na prática forense. Como metodologia do trabalho foi realizada uma revisão de literatura existente sobre o assunto, como o acesso a artigos publicados em periódicos disponibilizados em bases de dados como SciELO, PubMed, MEDLIN, com os descritores segundo o DeCS: medicina forense, antropologia forense e epigenética. A análise de alterações epigenéticas, pode ser uma ferramenta útil para a identificação de indivíduos, possibilita a avaliação de como e quando o material biológico foi exposto à cena de crime, além de estimatimar a idade dos envolvidos. Com base na revisão efetuada constata-se que a técnica baseada na metilação do DNA tem especificidade superior aos testes proteicos, pois elimina a detecção cruzada, evitando falsos positivos, e podem ser vistas como ferramentas valiosas e complementares nos estudos de genética forense, trazendo uma vantagem adicional aos métodos existentes. No entanto, outros estudos ainda devem ser desenvolvidos para que se tenha uma melhor caracterização do padrão de metilação humana.

Palavras-chave: Medicina forense; Antropologia forense; Epigenética. 
Abstract. Criminalistics always seeks to innovate their ideas to clarify the authorship and execution of a crime, in an undeniable way. For a long time, the search for polymorphisms in the sequence of DNA satellites or mitochondrial DNA has been applied in criminal identification. However, these methods carry limitations, although they are often used in forensic identification. Thus, this study aims at the possibility of the use of epigenetic techniques complementary to the techniques normally used in forensic genetics. The purpose of this literature review is to describe the use of epigenetic markers, in particular, DNA methylation in forensic practice. As a methodology of the work, a review of existing literature on the subject was done, such as access to articles published in journals published in databases such as SciELO, PubMed, MEDLIN, with the descriptors according to DeCS: forensic medicine, human anthropology and epigenetic. The analysis of epigenetic alterations can be a useful tool for the identification of individuals, allows the evaluation of how and when the biological material was exposed to the scene of the crime, besides estimating the age of those involved. Based on the review carried out, the technique based on DNA methylation has superior specificity to protein tests, since it eliminates crossdetection, avoiding false positives, and can be seen as valuable and complementary tools in forensic genetics studies, bringing an advantage of existing methods. However, other studies have yet to be developed to better characterize the human methylation pattern.

Keywords: Forensic medicine; Human anthropology; Epigenetic.

\section{Introdução}

A área da medicina forense e criminalística tem se renovando através da utilização de exames de DNA para a investigação de paternidade, elucidação de delitos e identificação de cadáveres. O sistema judiciário criminal segue empregando essa inovação tecnológica de DNA para analogias diretas de amostras de áreas de crime com as características de suspeitos eminentes. A hipótese de se alcançar suspeitos aumentará à medida em que o a quantidade de pessoas cujo DNA for analisado e incluído na análise de dados ${ }^{1}$.

O estudo das diversas regiões polimórficas do DNA humano, obtidos através de vestígios em áreas de crime, inclui consideravelmente as aplicações de sucesso na averiguação criminal ${ }^{2}$. A criminalística sempre busca inovar as suas ideias de maneira a esclarecer a autoria e execução de um crime, de forma inegável. Por um longo período, a pesquisa de polimorfismos na sequência de DNA satélites ou DNA mitocondrial vem sendo aplicada na identificação criminal. Entretanto, esses 
métodos carregam limitações, apesar de serem frequentemente utilizados na identificação forense ${ }^{3}$.

A identificação humana através do estudo de DNA é um importante instrumento nos estudos forenses, sendo admitido como evidência na maioria dos autos judiciais em todo o mundo. O perfil genético traz informação sobre a especificação étnica do indivíduo, e sobre o sexo, o que seria capaz de revelar alguma anomalia patológica, como as trissomias, ou mesmo um aspecto psicológica e social associada ao sexo. Além do que, não se despreza a possibilidade de que no futuro, os estudos do DNA não-codificante (ncDNA) abordem outros tipos de informação, como a cor dos olhos, afinal, os estudos genéticos são recentes na história da humanidade e avançam com muita rapidez ${ }^{4}$.

A análise de alterações epigenéticas, pode ser um método eficiente para a identificação de indivíduos. Essa investigação promove a avaliação de como e quando o material biológico foi submetido a cena de crime, além de identificar o tipo de material encontrado, permitindo também estabelecer a idade dos implicados. $O$ DNA empregue nestes processos é normalmente extraído de sangue, fio de cabelo, ossos, pele, sêmen, saliva ou urina ${ }^{5}$.

A característica principal da epigenética é a regulação da expressão gênica sem qualquer alteração na sequência de DNA, procura-se compreender o motivo pelo qual as células alteram as funções ao longo da vida, comportando-se diferentemente do que eram a princípio. As informações no epigenoma de um indivíduo são singulares, sendo que os fundamentos epigenéticos são suscetíveis às oscilações ambientais podendo causar mudanças fenotípicas, que serão disseminadas aos sucessores. Dessa maneira, a epigenética é definida como modificações legáveis na expressão do gene, que não alterem a sequência do DNA. São herdáveis pela mitose e durante as gerações, sendo uma maneira de tratar as mudanças que podem acontecer na expressão gênica 6 .

O termo epigenética foi introduzido por Conrad Waddington em 1942 para definir mudanças alteráveis e herdadas no genoma funcional. No fim dos anos 50 , 0 pesquisador geneticista Conrad, propôs pela primeira vez o termo epigenética, foi o primeiro cientista a conciliar os genes ao desenvolvimento ${ }^{7}$.

Todas as células do ser humano apresentam a mesma ordem de pares de bases no DNA, com ressalva dos clones de linfócitos $T$ e $B^{8}$. Ainda que partilhem 0 mesmo genoma, células de organismos multicelulares dispõem diversas morfologias 
e funções. Este fato é explicado por distinções quantitativas e qualitativas na expressão gênica, nos diversos tipos celulares de um indivíduo. Ao longo do desenvolvimento fetal, na diferenciação celular, há a possibilidade de um único genótipo fornecer diferentes fenótipos. Acreditou-se por muito tempo que todas as particularidades expressas em um indivíduo poderiam ser explicadas unicamente pelo seguimento de bases do DNA. Compreendeu-se que a sequência do código genético não seria capaz de por si só definir todos os aspectos de um indivíduo 9 .

A epigenética procura mostrar, por exemplo, o que diferencia dois alelos iguais e como esta diferenciação é automaticamente determinada e mantida através de gerações contínuas de células, e que distinções analisadas em gêmeos monozigóticos não os tornam completamente idênticos. Os gêmeos idênticos partilham uma sequência de DNA semelhante, e a sua identidade fenotípica é diversas vezes aplicada para acentuar o poder do significado da genética. No entanto, os gêmeos monozigóticos podem apresentar distinções fenotípicas extrínsecas certamente transmitidas por mudanças epigenéticas que transcorrer ao longo da vida dos indivíduos ${ }^{10}$.

Este trabalho é uma revisão sobre a possibilidade da utilização de técnicas epigenéticas complementares as técnicas padronizadas e utilizadas na genética forense. Este estudo tem como objetivo descrever o uso de marcadores epigenéticos, em particular a metilação do DNA na prática forense.

\section{Método}

Trata-se de um estudo de revisão integrativa de literatura, cuja estruturação da base teórica foi realizada a partir da pesquisa e análise de relevância histórica e contemporânea, em livros e artigos científicos em bases indexadas como Scielo, Bireme, LILACs, MEDLINE, Science Direct e PubMed. Esta revisão determina o conhecimento retrospectivo e atual sobre uma temática específica, já que é conduzida de modo a identificar, analisar e sintetizar resultados de estudos independentes sobre o mesmo assunto abordando o uso da epigenética na área forense. Para os estudos foram estabelecidos critérios de inclusão e exclusão de trabalhos científicos a partir dos seguintes descritores segundo o DeCS: medicina forense, antropologia forense, epigenética. 


\section{Revisão de literatura}

\subsection{Genética forense}

A genética forense aborda a utilização das experiências e das táticas em genética e biologia molecular na assessoria da justiça, englobando tanto a identificação cadavérica e de possíveis suspeitos quanto o exame de paternidade. O DNA empregado nestes processos é auferido de fios de cabelo, dente, sangue, dentre outros. Atualmente, os cientistas estão em melhor posição para analisar o material biológico, sendo ele de diversas naturezas, mesmo estando em quantias limitadas e degradadas ${ }^{11}$.

$\mathrm{O}$ avanço da genética forense iniciou-se a muito tempo com as pesquisas de Karl Landsteiner, médico austríaco, se predispôs a comprovar que existia diferenças no sangue de diversos indivíduos pela sua descoberta de polimorfismos do sistema $A B O$ no sangue humano, e pela rápida percepção que tais variações poderiam ser aplicáveis na solução de crimes $^{12}$.

Um estudo realizado nos laboratórios do Reino Unido, EUA e Canadá, em meados de 1980, demonstrou que o DNA que estava presente nas amostras forenses era suficiente para ser testado. Por volta de 1984, Alec Jeffreys, inovou com a descoberta do DNA "fingerprinting" que se baseia em um conjunto de marcadores genéticos nomeados minissatélites ou VNTR (sequências repetitivas de número variável), sendo específicas a um indivíduo. Essas regiões VNTR são altamente polimórficas, podendo ser utilizadas para diferenciar membros de uma população ${ }^{13}$.

Em 1985 foi aplicada uma análise molecular de material genético para solucionar um problema de imigração, Jeffreys empregou este método para identificar o legitimo estuprador e homicida de duas vítimas. A criminalística e a medicina forense vêm utilizando este método de tipagem molecular como potente arma de elucidação de variados delitos e identificação humana, a partir desse episódio que ficou conhecido como Enderby ${ }^{14}$.

O teste de DNA forense vem cumprindo um papel proeminente no âmbito da justiça, contribuindo na persuasão de culpados e exoneração de inocentes. A preservação de resquícios de DNA da cena do crime é crucial para desvendar delitos, além de se conceder provas objetivas ao sistema criminal ${ }^{15}$. 
A análise de DNA tornou-se indispensável e de rotina em análise de casos forenses correntes, aplicando técnicas excessivamente sensíveis para se averiguar cada material. Amostras escassas de DNA podem interligar suspeitos a diversas cenas de crime, como por exemplo, células epiteliais em um volante ou até mesmo saliva em uma ponta de cigarro ${ }^{1}$.

Testes de DNA que posteriormente demandavam várias semanas, agora podem ser realizados em poucas horas, através de inúmeros avanços em termos de capacidade de processamento da amostra e de sensibilidade. Na época atual, são necessárias pequenas quantidades de amostra com uma única célula, possibilitando construir um perfil único de DNA, ao invés de grandes manchas de sangue ${ }^{15}$.

\subsection{DNA}

A sigla DNA vem de ácido desoxirribonucleico, sendo localizada em uma organela denominada núcleo. Essa molécula transmite o código genético, dispõe de bases nitrogenadas, que são compostas por: citosina, timina, adenina, guanina (C, T, A e G). Além das bases nitrogenadas há uma molécula de açúcar, sendo unida a uma molécula de fosfato $^{16}$.

James Watson e Francis Crick caracterizaram o DNA, em 1953, como uma fita dupla helicoidal ao redor de um eixo, sendo fitas paralelas e suas bases nitrogenadas se encontravam direcionadas para a parte interna da hélice pareandose de forma complementar entre si. Tais bases nitrogenadas são conectadas por pontes de hidrogênio, que mantêm as fitas de DNA unidas. O DNA se envolve nas cromatinas, e estas por sua vez se enrolam sobre si mesmas, compondo as histonas, até formarem uma agregação gigante de poli nucleotídeos, ou seja, um conjunto amplo de diversos nucleotídeos, sendo nomeada de cromossomos ${ }^{17}$.

Há uma variação no sentido em que os nucleotídeos são adicionados, sendo um acontecimento resultante da seleção natural. No sentido de adição há uma intensificação da variedade genética entre os indivíduos de mesma espécie, simulando que eles não tenham as mesmas informações genéticas, pois senão, seriam clones uns dos outros ${ }^{18}$.

Mais de $90 \%$ do genoma humano consiste em sequências não codificantes entre os genes. Essas regiões contêm grande quantidade de DNA repetitivo. Repetições em tandem são unidades de repetição dispostas em sequência nas regiões não codificantes do DNA. DNA satélite é um tipo de sequência em tandem, 
pode ser encontrado nos centrômeros e telômeros, e é composto de longas sequências de repetições. Os minissatélites e microssatélites são dois outros tipos de repetições em tandem, sé que menores que o DNA satélite. Os minissatélites, também conhecidos como VNTR (número variável de repetições em tandem) são maiores, compostos de unidades de repetição de 10-100 nucleotídeos de extensão. Os microssatélites, também conhecidos como STR (repetição curta em tandem) ou SSR (repetição simples da sequência) possuem unidades de repetição de 2 a 6 nucleotídeos ${ }^{19}$.

Essas regiões são verificadas na identificação humana, pois são constituídas de sequências específicas de diferentes tamanhos, repetidas em tandem (lado a lado), em diferentes regiões do genoma (vários locl). O número de repetições dessas sequências muda entre os indivíduos, podendo ser empregadas para diferenciá-los. A maioria das sequências do genoma humano é semelhante entre diferentes indivíduos e as diferenças que ocorrem são chamadas de polimorfismos ${ }^{20}$.

Um segmento do DNA pode ser chamado de polimórfico quando sua frequência populacional é maior ou igual a $1 \%$. Um polimorfismo pode ser ocasionado em qualquer ponto do genoma, inclusive no meio de genes, sendo que muitos polimorfismos do DNA são úteis para estudos de mapeamento genético, denominados de marcadores de DNA ${ }^{21}$.

A maioria dos polimorfismos consiste de SNPs (single nucleotide polymorphism - polimorfismos de único nucleotídeo), que são mudanças em um único par de base ou mutação de ponto. Os polimorfismos de STR e VNTR também são muito úteis no contexto forense. Certos marcadores de DNA são extremamente polimórficos, e a variedade de unidades de repetição alterna entre os indivíduos de uma população. É duvidoso que dois indivíduos tenham exatamente a mesma combinação de polimorfismos, se um número adequado de marcadores for analisado. Portanto, um perfil genético pode ser utilizado para identificação humana ${ }^{22}$. Diversas técnicas podem ser aplicadas para análise da molécula de DNA (Tabela 1).

Entretanto, há limitações nas técnicas que envolvem o estudo direto do DNA. Na tipagem de alelos VNTR, sua desvantagem é requerer DNA íntegro e em grande quantidade, tornando praticamente inviável a tipagem de amostras biológicas antigas, degradadas ou com pouca quantidade de DNA, tornando-se pouco utilizada em investigações genéticas atualmente. $E$ foi com esse foco que a comunidade 
científica começou a procurar novos mecanismos que propiciassem a identificação humana com base nos fenômenos epigenéticos, ou seja, baseados nos processos que alteram o fenótipo do indivíduo, mas que não estão associados a mudanças na sequência de $\mathrm{DNA}^{23}$.

Tabela 1. Técnicas usadas para análise da molécula de DNA.

\begin{tabular}{|c|c|}
\hline $\begin{array}{l}\text { PCR - RFLP } \\
\text { (Polimorfismo de fragmentos } \\
\text { de restrição) }\end{array}$ & $\begin{array}{l}\text { Os marcadores VNTR são analisados através da } \\
\text { técnica PCR - RFLP, sendo baseada em mutações } \\
\text { que alteram sequências no DNA de um indivíduo. } \\
\text { Usa-se enzimas de restrição que clivam o DNA em } \\
\text { locais específicos, produzindo fragmentos de } \\
\text { diferentes comprimentos que são separados e } \\
\text { visualizados em forma de bandas. }\end{array}$ \\
\hline Sequenciamento do DNA & $\begin{array}{l}\text { A maior parte dos sequenciamentos de DNA é } \\
\text { executada através um método enzimático: o DNA a } \\
\text { ser sequenciado é fornecido na forma de fita simples, } \\
\text { a partir da qual a DNA polimerase sintetiza novas fitas } \\
\text { de DNA complementares. }\end{array}$ \\
\hline Eletroforese de DNA em gel & $\begin{array}{l}\text { Análise de polimorfismos de restrição (RFLP) e } \\
\text { análise de loci VNTR, em gel de agarose. A } \\
\text { eletroforese capilar é realizada sob condições } \\
\text { desnaturantes para propósitos forenses, como a } \\
\text { análise de STR. A matriz do capilar é composta de } \\
\text { poliacrilamida linear. }\end{array}$ \\
\hline $\begin{array}{l}\text { PCR } \\
\text { (Reação em cadeia } \\
\text { polimerase) }\end{array}$ & $\begin{array}{l}\text { Os STRs são analisados por meio de amplificação } \\
\text { por PCR, utilizando primers complementares as } \\
\text { regiões que flanqueiam as repetições STRs. A reação } \\
\text { em cadeia da polimerase é uma técnica in vitro que } \\
\text { permite à amplificação de sequências específicas de } \\
\text { DNA ou de RNA, sendo um método que utiliza duas } \\
\text { sequências de nucleotídeos iniciadoras, que } \\
\text { hibridizam com as fitas opostas, em regiões que } \\
\text { flanqueiam o segmento a ser amplificado. }\end{array}$ \\
\hline
\end{tabular}




\subsection{Epigenética}

A epigenética seria capaz de interferir em vários processos biológicos do organismo, apesar de compreender-se a maneira na qual seria feita a transferência das informações genéticas nas células ${ }^{24}$.

A epigenética busca explicar o que distingue dois alelos iguais e como é esta distinção mecanicamente determinada e mantida, através de gerações contínuas de células. E como as diversidades identificadas em gêmeos monozigóticos não os tornam plenamente idênticos. É um meio de expor as alterações que podem ser predeterminadas na expressão gênica, sem que haja variações na sequência do DNA. Busca compreender o por que as células alteram de funções ao longo da vida, podendo funcionar ou comportar-se de maneira distinta do que era a princípio, mesmo o DNA permanecendo inalterado ${ }^{25}$.

A informação genética perdura-se no processo epigênico, contudo o processo de transcrição celular poderá sofrer interferências epigenéticas ao acessar essa informação, por intermédio de mudanças bioquímicas que acontecem na compactação do DNA. Ao passo que decorre essa compactação haverá maior ou menor viabilização do DNA para a transcrição ser provocada ${ }^{26}$.

Os eventos de metilação do DNA podem ser percebidos como significativos indicadores epigenéticos sendo ponderosos nos estudos forenses, em especial em situações de investigações de paternidade, podendo ser um complemento eficiente para os marcadores genéticos tradicionais na identificação de tecidos e fluidos, distinção de gêmeos monozigóticos, estimativa de idade, obtenção da causa e circunstâncias de óbito e ainda associar inúmeros marcadores epigenéticos com doenças neuropsiquiátricas ${ }^{27}$.

A epigenética pode ser estável e hereditária, e ser originada por alterações ao nível de metilação do DNA, da apuração da transcrição, do domínio da tradução ou de modificações pós-tradução. $O$ advento do mecanismo epigenético é incitado através de reações químicas moleculares, essas ligações químicas determinam a expressão epigênica de uma célula. Todavia, essa compreensão não era capaz de explicar as diferenças fenotípicas dentre gêmeos monozigóticos ao longo do desenvolvimento. Assim, notou-se que a sequência do código genético não seria capaz de por si só, definir todos os traços de um indivíduo ${ }^{10}$.

Os mais importantes mecanismos de regulação epigenética descritos são: modificações pós-traducionais de histonas, ação de ncRNA (RNA não-codificante) e 
a metilação do DNA. As proteínas de maior importância na estrutura da cromatina, conhecidas como histonas, podem sofrer modificações químicas como a inclusão de grupos acetil, metil, fosforil, de ubiquitina etc. Da mesma forma, a ação de ncRNA intervêm na estabilidade de RNAm (RNA mensageiro), na tradução de RNAm e na conformação da cromatina. Já a metilação do DNA, é caracterizada como a modificação epigenética mais frequentemente observada e origina-se rapidamente na molécula de $\mathrm{DNA}^{28}$.

\subsection{Marcadores epigenéticos com aplicação forense}

A análise de DNA em âmbito forense não pode, por si só, comprovar a culpa do criminoso ou a inculpabilidade do mesmo, no entanto, pode estipular uma correlação entre o acusado e a cena do crime. Todavia, há limites nas técnicas que circundam o estudo do DNA e foi com o foco nessas situações que inúmeros investigadores experimentaram investigar novas técnicas que proporcionassem a identificação humana com base nos mecanismos epigenéticos, como o caso da metilação do DNA, por exemplo29.

Visto que, a metilação do DNA é o mecanismo primário de regulagem epigênica que abrange um papel importante no desenvolvimento e distinção celular. É um processo que afeta mecanismos celulares através da mudança de expressão gênica. Essa reação origina-se por meio da mudança de um grupo metil para o carbono de número cinco da molécula de citosina, formando a 5-metilcitosina, assim como demonstra a figura $1^{30}$.

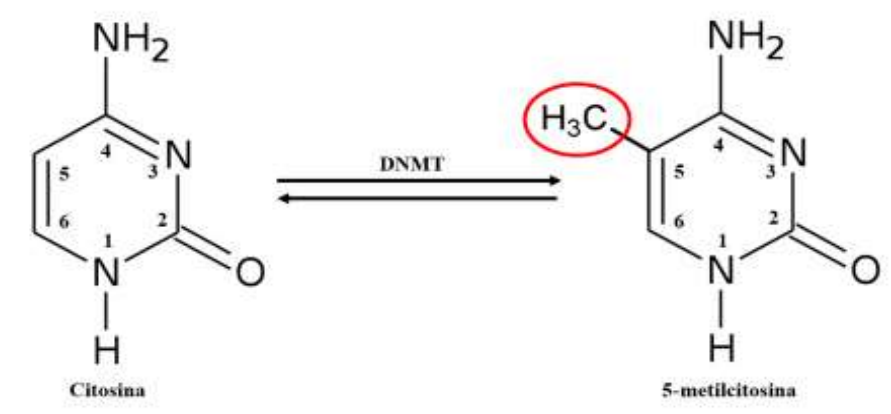

Figura 1. Representação da reação de metilação da citosina no DNA.

A metilação das citosinas não decorre uniformemente ao longo da molécula de DNA, estima -se que apenas $3 \%$ das citosinas são metiladas. A metilação ocorre 
em local específico na cromatina, não é ao acaso. Tem de haver uma pré-disposição química para que possa ocorrê-la. A pré-disposição química para a metilação do DNA ocorre nos dinucleotídeos CpG. Estas regiões possuem longa extensão e se sobrepõem a aproximadamente $70 \%$ dos genes em humanos, sendo localizadas preferencialmente junto a promotores gênicos ${ }^{31}$.

O processo de metilação é mediado por enzimas da família DNA metiltransferase (DNMT), que catalisam e transferem o grupamento metil para as bases de citosina na molécula de DNA. Após a replicação do DNA, as DNMTs fazem o reconhecimento dos dinucleotídeos $\mathrm{CpG}$ e inicia-se a metilação do DNA. A metilação do DNA muda a expressão gênica, contudo esse processo é complexo, pois as condições ambientais exercem influências sobre a metilação do DNA. A nutrição, o estilo de vida e o estresse pode intervir nos mecanismos de modificação da expressão gênica ${ }^{32}$.

A metilação de citosinas do DNA é um indicio específico no código genético para recrutar e interagir com proteínas de ligação a domínios metil-CpG (MBD). Essas proteínas distinguem e se ligam às citosinas metiladas e, por sua vez, propiciam o recrutamento de enzimas, tais como histona metiltransferase (HMT) e histona deacetilase (HDAC) que resultam a compactação da cromatina, tornando a região transcricionalmente inativa. Além do que, a metilação de ilhas $\mathrm{CpG}$ também é apta de dificultar diretamente a interação entre os promotores gênicos e complexos transcricionais ${ }^{8}$.

Portanto, a metilação de citosinas do DNA é definida como um mecanismo de inibição da expressão gênica. A metilação impacta a base da molécula de DNA, e, portanto, o desenvolvimento da célula. As sequências ausentes de metilação estão sendo transcritas ativamente, enquanto as sequências metiladas não são transcritas $^{33}$. As ilhas $\mathrm{CpG}$ são miras de proteínas que se agregam com os $\mathrm{CpG}$ não metilados e desencadeiam a transcrição do gene. Tradicionalmente as áreas não metiladas das áreas CpG são encontradas em genes de tecidos específicos e em genes primordiais, como os de manutenção que estão implicados na conservação da prática celular e são expressos na maior parte dos tecidos. Dessa maneira o grau de metilação influencia a sua expressão: quanto mais metilado estiver um gene, menor será o seu nível de expressão ${ }^{34}$.

As mudanças nos padrões de metilação de DNA pode acontecer durante toda a vida de um indivíduo, certas modificações podem ser um feedback fisiológico 
a alterações ambientais ou a processos patológicos, como a transformação oncogênica ou senescência celular. No entanto, os aspectos intrínsecos e ambientais que induzem alterações de metilação do DNA encontram-se desconhecidos ${ }^{35}$.

Um dos processos que melhor estabelece a modificação do fenótipo do indivíduo seria a metilação do DNA, que pode ser visto como principal marcador epigenético. Podendo também oferecer dicas sobre estados patológicos, distinção de gêmeos idênticos, circunstâncias que encadeiam o óbito e até o tipo de tecido ${ }^{36}$.

Os ensaios alicerçados no uso de marcadores epigenéticos podem ser muito benéficos numa diversidade de utilizações forenses em comparação com várias proteínas ou métodos baseados em RNA. No entanto, é preciso cuidado extra na seleção de áreas $\mathrm{CpG}$, bem como a compreensão dos perfis de metilação analisados. O primeiro passo num estudo epigenético bem-sucedido é a identificação de marcadores de metilação de DNA adequados. Em uma análise de metilação do DNA do genoma é muito provável descobrir várias regiões genômicas nunca vistas que apresentam variações epigenéticas, inclusive aquelas que estão localizadas fora de promotores de genes. Os métodos usados são apenas para uma primeira triagem e identificação de um conjunto de áreas $\mathrm{CpG}$, necessitando após isso a validação dos marcadores selecionados ${ }^{37}$.

Em todos os ensaios forenses, os critérios de validação devem ser rigorosos e têm de ser cumpridos para cada marcador epigenético selecionado. Todos os marcadores demandam apresentar uma elevada sensibilidade e especificidade, uma vez que as amostras forenses são frequentemente de baixa qualidade e quantidade. Existem métodos para analisar a metilação do DNA, como por exemplo a conversão por bissulfito. A conversão por bissulfito é utilizada para desaminar citosinas não metiladas convertendo em uracila. As citosinas metiladas são protegidas da conversão com bissulfito, uma vez que a conversão das citosinas não metiladas tenham ocorrido, as diferenças entre citosinas metiladas e não metiladas (convertidas em uracilas) podem ser analisadas por vários métodos, entre eles, sequenciamento, perfil de digestão ou PCR quantitativo (qPCR) ${ }^{38}$.

Aspectos ambientais, tais como a senescência, stress ambiental, doenças, cancro, tabagismo e outros, podem intervir nos padrões de metilação do DNA, alterando-os. Além disto a influência dos aspectos ambientais tem de ser validada em situações de aplicação forense ${ }^{36}$. 
Nas situações em que as condições de metilação do DNA podem ser quantificados, é essencial escolher áreas CpG que possuem nitidamente um alto grau de diferença de metilação, para alcançar uma maior margem e diferenciação. Por exemplo, a fim de correlacionar um local CpG específico com uma determinada causa de óbito como o abuso de drogas, a metilação desse local CpG precisa constatar no mínimo uma diferença entre 60-70 \% em comparação com o tecido normal. Isso também evita falsas estimativas devido à grande oscilação intraindividual ${ }^{39}$.

Adicionalmente, o estudo da metilação do DNA também tem um papel ativo no ramo de autenticação de amostras. Visto que nos dias atuais é possível sintetizar DNA, e isso torna-se um problema nas cenas de crime pois o DNA artificial pode ser introduzido nas mesmas. Vários estudos apontam que no DNA artificial todos os loci são não metilados enquanto no DNA natural certos loci são metilados, o que faz com que o uso de um método baseado na metilação do DNA detecte DNA artificial e os consiga excluir imediatamente da cena de crime ${ }^{29}$.

Os padrões de metilação do DNA tem sido estudado principalmente por três razões forenses relevantes: i) identificar a fonte de DNA do tipo tecido / célula, ii) estimar a idade de um indivíduo, e iii) diferenciar gêmeos monozigóticos ${ }^{40}$.

Em pesquisa publicada previamente, foram descritos um conjunto de marcadores epigenéticos, ZC3H12D, BCAS4 e cg-06379435, capazes de produzir padrões únicos e específicos de metilação de DNA que podem ser utilizados para identificar sêmen, saliva e sangue, respectivamente. Esses marcadores epigenéticos demonstram sensibilidade, especificidade, resistência à degradação e revela a capacidade na determinação dos níveis de traços de fluidos corporais ${ }^{41}$.

Os marcadores ZC3H12D e BCAS4 têm como alvo cinco sítios CpG na sequência a ser analisada. Os dados mostram que o locus BCAS4 é hipermetilado em amostras de saliva quando comparadas a outras amostras de fluidos biológicos ${ }^{42}$. Já o loci ZC3H12D mostra-se hipometilado em amostras de sêmen quando comparadas a outras amostras de fluídos biológicos. E o marcador cg06379435 tem como alvo apenas um sítio CpG na sequência a ser analisada ${ }^{27}$.

Existem evidencias na atualidade de que os gêmeos monozigóticos podem demonstrar um grau muito pequeno de diferenças genéticas, em relação aos SNPS, nas variações no número de cópias, entre outros. No entanto essas diferenças são extremamente raras e difíceis de se localizar. A epigenética observada nos pares de 
gêmeos monozigóticos pode ser analisada em um nível genômico amplo e também em locus específicos, que estão provavelmente ligados à regulação gênica envolvida em fenótipos específicos ${ }^{43}$.

A utilização de um kit como o Illumina Infinium Human Methylation 27K BeadChip, permitiu que Li et al. ${ }^{44}$ testassem amostras de DNA de 22 pares de gêmeos adultos monozigóticos, analisando 27.578 sítios $\mathrm{CpG}$, sendo revelado diferenças significativas na metilação do DNA. A maioria desses marcadores está associada diferenciação celular, proliferação e desenvolvimento, sendo assim uma proposta com uma abordagem adequada para superar desafio da diferenciação de gêmeos monozigóticos ${ }^{45}$.

Durante o processo de senescência ocorrem alterações de biomoléculas no nível molecular, principalmente na molécula de DNA. Dessa maneira, encontrar biomarcadores baseados no DNA é ideal e de muita aplicação prática na predição de idade em análises forenses. A metilação do DNA desempenha um papel importante no envelhecimento celular e do organismo. Diversos estudos investigaram o estado epigenético de diversos genes ou ilhas $\mathrm{CpG}$ em indivíduos de várias idades, e mediram as mudanças globais na metilação do DNA com o aumento da idade ${ }^{10}$.

Um método promissor para previsão de idade, mais preciso, surgiru do campo da epigenética, onde uma significativa alteração dos níveis globais de metilação do DNA foi observada por estar associada ao aumento da idade. Para estimar a idade utilizando-se marcadores, Freire-Aradas et al. ${ }^{46}$ investigaram os padrões de metilação de 177 locais CpG de 22 regiões genômicas candidatas em 725 indivíduos de ascendência europeia (18 -104 anos) e estabeleceram um novo modelo de previsão de idade de loci-correlacionados em ELOVL2, PDE4C, FHL2, ASPA, CCDC102B, C1orf132 e chr16: 85395429. Os autores encontraram uma progressão significativa da metilação do DNA aumentando com a idade em ELOVL2, PDE4C e FHL2 e redução da metilação em ASPA, CCDC102B, C1orf132 e chr16: $85395429^{46}$.

A variabilidade da estimativa de idade baseada na metilação precisa ser investigada geograficamente, já que diferentes populações têm diferentes condições de saúde, estilos de vida e exposição ao clima e fatores ambientais que podem afetar as estimativas. Por sua vez, o enfoque forense em encontrar e validar marcadores que mostrem associações fortes, robustas e reprodutíveis com a idade 
cronológica entre indivíduos variados pode refletir em uma pesquisa mais fundamental sobre o processo de envelhecimento ${ }^{47}$.

No entanto, para assegurar a eficácia desses marcadores, estudos de validação precisam ser realizados para determinar as condições e limitações desta nova ferramenta para análise forense. No cenário atual, é necessário mapear e identificar mais marcadores de metilação em diferentes tecidos, aumentando a quantidade de marcadores disponíveis e contribuindo para uma estimativa de idade mais precisa ${ }^{48}$.

\section{Considerações finais}

Os métodos clássicos utilizados na área forense apontam algumas desvantagens, como o consumo da amostra e, consequentemente do DNA presente. A metilação do DNA é bem apropriada para a detecção e identificação de fluidos corporais, essa técnica tem especificidade superior aos testes proteicos, uma vez que elimina a detecção cruzada. As técnicas que utilizam mecanismos de metilação do DNA podem ser vistas como ferramentas importantes e complementares, é uma forma de distinguir gêmeos iguais analisando o padrão de metilação em certas regiões CpG, contudo outros estudos ainda necessitam ser desenvolvidos para que se tenha uma melhor definição do padrão de metilação humana.

\section{Referências}

1. Jobling MA, Gill P. Encoded evidence: DNA in forensic analysis, Nature Reviews Genetics, 2004; v. 5, n. 10, p. 739-751. https://doi.org/10.1038/nrg1455

2. Guillén M. Ethical-legal problems of DNA databases in criminal investigation. Journal of Medical Ethics, 2000; v.26, p. 266-71. https://doi.org/10.1136/jme.26.4.266

3. Gunn P, Walsh SJ, Roux C. The nucleic acid revolution continues-will forensic biology become forensic molecular biology? Frontiers in genetics, 2014; v. 5, p. 44. https://doi.org/10.3389/fgene.2014.00044

4. Casabona CMR, Malanda SR. Los Identificadores del ADN en el Sistema de Justicia Penal. Revista Derecho y Proceso Penal. 2010; n²3, Arazandi.

5. Kader F, Ghai M. DNA methylation and application in forensic sciences. Forensic $\begin{array}{lllll}\text { science } \quad \text { international. } 2015 ; \quad \text { v. } & 249, \quad \text { p. }\end{array}$ https://doi.org/10.1016/j.forsciint.2015.01.037 
6. Fantappié M. Epigenética e Memória Celular. 2013. Disponível em: http://revistacarbono.com/artigos/03-epigenetica-e-memoria-celular-marcelofantappie/ . Acesso em: 30 de janeiro de 2018.

7. Klose RJ, Bird AP. Genomic DNA methylation: the mark and its mediators, Trends. Biochem. Sci. 31. 2006; 89-97. https://doi.org/10.1016/j.tibs.2005.12.008

8. McQueen C. Comprehensive toxicology. 2010; v. 2. cap. 2.18. Newnes.

9. Jablonka E, Lamb MJ. Epigenetic Inheritance. International Encyclopedia of the Social \& Behavioral Sciences. 2015; $2^{\mathrm{a}}$ Ed. Elsevier, Oxford, p. 832-838. https://doi.org/10.1016/B978-0-08-097086-8.81004-1

10. Fraga MF, Esteller M. Epigenetic differences arise during the lifetime of monozygotic twins. Proceedings of the National Academy of Sciences of the United States of America. 2005;102(30): p. 10604-10609. https://doi.org/10.1073/pnas.0500398102

11. Alberi E. Perícia Criminal e Cível: Uma Visão Geral Para Peritos e Usuários da Perícia. 2011; 3를 Ed, Campinas: Millenium, p. 512.

12. Bonaccorso NS. Elaboração de laudos e relatórios de análise de exames de DNA realizados pelo Instituto de Criminalística de São Paulo. Arquivos da Polícia-CivilRevista Tecnocientífica. 2001; São Paulo: Acadepol, v.46, n.1.

13. NRC. Conselho Nacional de Pesquisa. Tecnologia do DNA na ciência forense. Comitê sobre Tecnologia do DNA na Ciência Forense, Conselho de Biologia Comissão sobre Ciências da Vida. 1999; Ribeirão Preto: FUNPEC-RP, p. 202.

14. Moura NRS. A Investigação de Crimes Sexuais através do Estudo do DNA. Rev. Panorama da Justiça. 1998; n.10.

15. Butler JM. The future of forensic DNA analysis. Philosophical transactions of the Royal Society of London, London. 2015., v. 370, n. 1674, p. 1-10.

16. Junqueira LC, Carneiro J. Biologia celular e molecular. 1991; 5 ed. Rio de Janeiro: Guanabara Koogan.

17. Watson JD, Gilmam M, Witkowshi J, Zoller M. O DNA recombinante. Editora UFOP. 1997.

18. Amabis JM, Martho GR. Biologia das Células, v. 1, Biologia dos Organismos, Vol. 2, Biologia das Populações. 2010; Vol. 3, São Paulo, Ed. Moderna.

19. Rodrigues, CDF. Francez, PAC. Introdução à Biologia Forense. 2018; Millennium Editora. $2^{\mathrm{a}}$ edição.

20. Lopes S. Biologia. 2010; v. 3, São Paulo, Ed.: Saraiva.

21. LI, R. Forensic Biology. CRC Press Taylor \& Francis Group. 2015; 2nd Edition.

22. Verga L. Marcadores moleculares. 2018.2 Disponível em: http://www.ib.usp.br/evolucao/QTL/marcadores.html . Acesso em: 31 jan. 2018. 
23. Bucholtz A, Davis A. Forensic Studies: CSI for the Nonscientist: From crime scene to crime lab. 2011; San Clemente: Law Tech Publishing Group.

24. Oliveira JC. Epigenética e doenças humanas. Semina: Ciências Biológicas e da Saúde, Londrina. 2012; v.33, n.1, p. 21-34, jan./jun.

25. Lamb MJ, Jablonka E. Epigenetic Inheritance. International Encyclopedia of the Social \& Behavioral Sciences. 2015; $2^{\mathrm{a}}$ Ed. Elsevier, Oxford, p. 832-838.

26. Prado KB. Epigenética: um novo campo da genética. RUBS, Curitiba. 2008v.1, n.3, p.61-69, set./dez.

27. Park JL. Identification and evaluation of age-correlated DNA methylation markers for forensic use. Forensic Science International: Genetics. 2016; v. 23, p. 64-70. https://doi.org/10.1016/j.fsigen.2016.03.005

28. Turner JD, Kirschner SA, Molitor AM, Evdokimov K, Muller CP. Epigenetics. International Encyclopedia of the Social \& Behavioral Sciences. 2015; 2 ${ }^{\mathrm{a}}$ Ed. Elsevier, Oxford, p. 839-847. https://doi.org/10.1016/B978-0-08-097086-8.14142-X

29. Muller HR, Prado KB. Epigenética: Um Novo Campo da Genética. 2008; RUBS 1(3), 61 69.

30. Leenen

D. Mecanismos

Epigenéticos.

2016.

Disponível

em: http://ead.hemocentro.fmrp.usp.br/joomla/index.php/noticias/adotepauta/669mecanismos-epigeneticos . Acesso em: 31 jan. 2018.

31. Skalnik DG. Chromatin: Methyl-CpG-Binding Proteins. 2013; Elsevier.

32. Garinis GA, Patrinos GP, Spanakis NE, Menounos, PG. DNA hipermethylation: when tumour supressor genes go silent. 2002; Hum Genet. 111:115-27. https://doi.org/10.1007/s00439-002-0783-6

33. Aliss CD, Reinberg DJT, Caparros M. Epigenetics. 2007; ed. T.J. Danny Reinberg, New York: Cold Spring Harbor, p. 502.

34. D' Alessio AC, Szyf, M. Epigenetic tête-à_tête: the bilateral relantionship between chromatin modifications and DNA methylation. Biochem Cell Biol; 84:463-76, 2006.

35. Frumkin D. DNA methylation-based forensic tissue identification. Forensic Science International-Genetics. 2011.p. 517-524. https://doi.org/10.1016/j.fsigen.2010.12.001

36. Bock C. Epigenetic biomarker development. Epigenomics. 2009; 1(1): p. 99-110. https://doi.org/10.2217/epi.09.6

37. Bird A. DNA methylation patterns and epigenetic memory. Genes \& Development, 2002. 16(1): p. 6-21. https://doi.org/10.1101/gad.947102

38. Budowle B, Daal, A. Extracting evidence from forensic DNA analyses: future molecular biology directions. Biotechniques. 2009; 46(5): p. 339. https://doi.org/10.2144/000113136

39. Tollefsbol T. Handbook of Epigenetics: The New Molecular and Medical Genetics. 2011; London: Elsevier Inc. 
40. Freire-Aradas A, Phillips C, Lareu MV. Forensic Individual Age Estimation with DNAFrom Initial Approaches to Methylation Tests. Forensic Sci Rev. 2017; 29(2):121-144.

41. Silva DSBS, Antunes J, Balamurugan K, Duncan G, S.Alho C, McCord B. Developmental validation studies of epigenetic DNA methylation markers for the detection of blood, semen and saliva samples, Forensic Sci Int Genet. 2016; 23:55-63. https://doi.org/10.1016/j.fsigen.2016.01.017

42. Madi T, Balamurugan K, Bombardi R, Duncan G, Mccord B. The determination of tissuespecific DNA methylation patterns in forensic biofluids using bisulfite modification and $\begin{array}{lll}\text { pyrosequencing. } \quad \text { Electrophoresis. } & \text { 2012; }\end{array}$ https://doi.org/10.1002/elps.201100711

43. Pirazzini C, Giuliani C, Bacalini MG, Boattini A, Capri M, Fontanesi E, et al., Space/Population and Time/Age in DNA methylation variability in humans: a study on IGF2/H19 locus in different Italian populations and in mono and di-zygotic twins of different age. Aging (Albany NY). 2012; 4(7):509-20. https://doi.org/10.18632/aging.100476

44. Li C, Zhang S, Que T, Li L, Zhao S. Identical but not the same: the value of DNA methylation profiling in forensic discrimination within monozygotic twins, Forensic Sci. Int. 2011, 3; 337-e338.

45. Vidaki A, Kayser M. Recent progress, methods and perspectives in forensic epigenetics. Forensic Sci Int Genet. 2018; 37:180-195. https://doi.org/10.1016/j.fsigen.2018.08.008

46. Freire-Aradas A, Phillips C, Mosquera-Miguel A, Giron-Santamaria L, Gomez-Tato A, Casares de $\mathrm{CM}$, et al. Development of a methylation marker set for forensic age estimation using analysis of public methylation data and the age. Bioscience EpiTYPER system. Forensic Sci Int Genet, 2016; 24: 65-74. https://doi.org/10.1016/j.fsigen.2016.06.005

47. Parson W. Age Estimation with DNA: From Forensic DNA Fingerprinting to Forensic (Epi)Genomics: A Mini-Review. Gerontology. 2018; 64(4):326-332. https://doi.org/10.1159/000486239

48. Hannum G, Guinney J, Zhao L, Zhang L, Hughes G, Sadda S, Klotzle B, Bibikova M, Fan JB, Gao Y, Deconde R, Chen M, Rajapakse I, Friend S, Ideker T, Zhang K. Genome-wide Methylation Profiles Reveal Quantitative Views of Human Aging Rates. Mol Cell. 2013; 49(2):359-367. https://doi.org/10.1016/j.molcel.2012.10.016 